\title{
IAMJ
}

INTERNATIONAL

AYURVEDIC

MEDICAL JOURNAL

\section{CRITICAL STUDY OF HYPOTHYROIDISM IN THE LIGHT OF AYURVED PERSPECTIVE}

\section{$\underline{\text { Welde Amruta }}^{1}$, Pawar Pradeep $^{2}$}

${ }^{1}$ P.G. Scholar, Department of Ayurved Samhita and Siddhant, Pravara Medical Trust Ayurved Mahavidyalaya and Shri Sant Eknath Rugnalaya, Shevgaon, Ahmednagar, Maharashtra, India.

${ }^{2}$ Asso. Professor, Department of Ayurved Samhita and Siddhant, Pravara Medical Trust Ayurved Mahavidyalaya and Shri Sant Eknath Rugnalaya, Shevgaon, Ahmednagar, Maharashtra, India.

Corresponding Author: amrutakulkarni28102017@gmail.com

https://doi.org/10.46607/iamj2709112021

(Published Online: November 2021)

Open Access

(C) International Ayurvedic Medical Journal, India

Article Received:20/10//2021 - Peer Reviewed:30/10/2021 - Accepted for Publication:31/10/2021

\section{Check for updates}

\section{ABSTRACT}

There is no exact correlation between the Thyroid gland and Hypothyroidism in Ayurveda. But the function of the Thyroid gland can be compared with the action of Agni, Tridosha and Dhatus. However, the symptoms of Hypothyroidism are correlated with the symptoms of Ama, Ojovyapat, Kaphavritta Udana. If we find the type of disease, then all endocrine disorders are Adhyatmik Vyadhi which is described in Sushrut Samhita. Causative factors of Adhyatmik Vyadhi are perfectly matched with Hypothyroidism in the present era. Ayurveda is one of the oldest and purest forms of treatment available today. Ayurveda always emphasizes that, if you won't find the disease in Samhita/Text, then fit all the symptoms of that disease in its basic principles and then treat it as per Ayurvedic perspective. Now a days, different types of symptoms are seen in different types of people, as Hypothyroidism involves impairment of various systems i.e., strotas. Due to the advancement of technology and instrumentation, it is easier to diagnose Hypothyroidism based on a pathological investigation. But modern management of Hypothyroidism is not satisfactory. That's why for safe, effective, and preventive management, find the pathogenesis of disorders according to the Ayurvedic perspective. 
Keywords: Hypothyroidism, Agni, Tridosha, Dhatu, Ama, Ojovyapat, Kaphavritta Udana.

\section{INTRODUCTION}

In the present era, no of people are suffering from Thyroid problems and the reasons are unhealthy, inactive food, stressful lifestyle, unwanted medicines like contraceptive pills, long term use of higher medicines, antibiotics, hereditary, etc. And it causes malfunctioning of the Thyroid gland. Due to malfunctioning, the Thyroid gland doesn't work properly. It causes an overall imbalance in the form of fatigue, a sudden increase in weight, a sudden decrease in weight, hair fall, bulging eyes, mood swings, depression, menstrual disorders, infertility; etc. The thyroid gland is the most important part of the endocrine system, situated in the lower part of the front and side of the neck. T3 and T4 are two primary hormones produced by the Thyroid gland ${ }^{(1)}$. There is no exact description of the thyroid gland in Ayurveda, but the functionality can be correlated with the function of Agni, Tridosha, Dhatus. There are many allied complaints of thyroid problems, of which Hypothyroidism is the most commonly seen problem in clinical practice. When the Thyroid gland is inactive and not able to produce enough hormones, is called Hypothyroidism. It can be compared with symptoms of Ama, Ojovyapat, Kaphavritta Udana. The prevalence of Hypothyroidism in the overall study population was $10.95 \%$. The prevalence of hypothyroidism in adults is very high in this era ${ }^{(2)}$. In women, the prevalence was higher at $11.4 \%$ when compared with men ${ }^{(3)}$. Even though, modern management of Hypothyroidism will only manage the hormonal imbalance. But side effects and complications of these Excessive hormonal replacement therapy are very serious, long term and dangerous to health. Hence, to control these complications this is the attempt regarding this topic that to study the concept of hypothyroidism from various points of view of Ayurvedic principles for further safe, effective, and preventive management.

\section{MATERIAL AND METHOD}

- The study was carried out by literature search.

- The study of various classical Ayurvedic texts.

- Research papers, online data, related websites.

- All the information has been analyzed to understand Hypothyroidism according to the Ayurvedic view.

\section{Analysis of Thyroid hormones function in Ayur-} vedic view:

There is no exact correlation between the Thyroid gland in Ayurveda. But, the functions of the thyroid gland can be correlated with the action of Agni, Tridosha, 7 Dhatus predominantly.

\section{Involvement of Doshas:}

All neurological regulations of the endocrine gland are performed by Vatadosha. The thyroxine hormone of the thyroid gland can be correlated with the function of the pitta. Pitta is responsible for all kind of metabolism. Here, it should be made clear that BMR is regulated by pitta ${ }^{(4)}$.

\section{Functions of Agni:}

Agni is an important factor of digestion and metabolism in our body. Ayurveda described that Agni (Dehagni) is the cause of life, colours, strength, health, enthusiasm, Plumpness, complexion, Oja, Teja(energy), other varieties of Agni and prana (life energy) ${ }^{(5)}$.

Agni is classified into 3 groups i.e., Jatharagni, Bhutagni, Dhatwagni ${ }^{(6)}$.

Table 1:

1.Jatharagni $\quad$ Present in stomach and duodenum. Basic functions are macro digestion of food.

2. Bhutagni present in 5 bhutas i.e., prithvi, aap, tej, vayu, aakash. The basic function is micro digestion of food i.e., nourishing their own specific element of the body.

3. Dhatwagni All 7 dhatwagni contains their own Agni to metabolize the nutrient material supplied to them through their own strotas. It gives strength and nourishment to other Agni in the body. 
Table 2: Correlation of functions of Agni with functions of thyroid hormones

\begin{tabular}{|l|l|}
\hline Functions of Agni $^{(\mathbf{5 , 7})}$ & Functions of Thyroid Hormones \\
\hline 1. Paka & $\begin{array}{l}\text { - calorigenic action } \\
\text { - Regulates metabolism of carbohydrates and fats. } \\
\text {-Synthesis of proteins in the cells. }\end{array}$ \\
\hline 2. Bala & essential for the normal activity of skeletal muscles. \\
\hline $\mathbf{3 .}$ Utsaha & essential for normal sexual function. \\
\hline 4. Ushma & Induced thermogenesis \\
\hline $\mathbf{5 . ~}$ Kshudha & Decreases secretion and movement of GI Tract \\
\hline 6. Medha & $\begin{array}{l}\text { - stimulating factors for the nervous system. } \\
\text { - increases blood circulation to the brain. }\end{array}$ \\
\hline 7. Varna & necessary factor for Erythropoiesis. \\
\hline
\end{tabular}

Table 3: Correlation of functions of Dhatus with functions of Thyroid hormones:

\begin{tabular}{|c|c|c|}
\hline Dhatus & Functions of Dhatu $^{(9)}$ & Functions of Thyroid hormones ${ }^{(8)}$ \\
\hline 1. Ras & Preenana & Thyroxine has a direct effect on the heart. \\
\hline 2. Rakta & Jeevana & One of the important general factors necessary for erythropoiesis. \\
\hline 3. Mamsa & Lepa & Essential for normal Activities of skeletal muscles. \\
\hline 4. Meda & Snehana & maintaining the weight of the body. \\
\hline 5. Asthi & Dharana & $\begin{array}{l}\text { The general and specific effect on growth. } \\
\text { Closure of epiphysis under the influence of thyroxine. }\end{array}$ \\
\hline 6. Majja & Purana & Essential for the development and the normal functions of CNS. \\
\hline 7. Shukra & Garbhotpadana & Essential for normal sexual function. \\
\hline
\end{tabular}

\section{Concepts of Hypothyroidism:}

Hypothyroidism is the condition resulting from a lack of effects of thyroid hormones on body tissues. Primary hypothyroidism is due to disease of the thyroid itself and secondary hypothyroidism is due to TSH deficiency ${ }^{(10)}$.

\section{Analysis of Hypothyroidism in Ayurvedic view:}

- Ashtoninditiya purush-In Charaka samhita, Ashtoninditiya purushas have been described very well, which can be taken as functional disorders of the endocrine gland, from which signs and symptoms of Sthaulya i.e. sthulata (weight gain), Ayushorhas (morbidity due to complications such as cardiovascular diseases), Javoparodha (Lethargy), Krucchravyavay (loss of libido), daurbalya (fatigue, weakness), swedbaddha (decrease in sweat), atikshut (increase in appetite), atipipasa (increase in thirst), etc. are nearly similar to signs and symptoms of hypothyroidism $^{(11)}$.
- Adhyatmik vyadhi- Endocrine disorders are an Adhyatmik vyadhi as per Ayurveda, which is mentioned in Sushrut samhita. Atma is the context that means the body along with the mind. The diseases manifesting in the body and mind level, are called Adhyatmik vyadhi ${ }^{(12)}$. They are of 3 types:

1. Adibalapravritta vyadhi-caused due to morbidity of ovum and sperm (hereditary hypothyroidism)

2. Janmabalapravritta vyadhi- the disease which occurs in a child due to improper diet and lifestyle practices followed by the mother during the conception and developmental stages of the foetus. (Congenital hypothyroidism)

3. Doshabalpravritta vyadhi-the diseases caused due to imbalance of vata, pitta, kapha and due to faulty diet and behaviour, upheaves of the two manasik doshas i.e., rajas and tamas.

\section{- Galganda-}

There is no direct mention of thyroid disorders in Ayurveda, but the disease Galganda is directly men- 
tioned in various Ayurveda Samhitas. Galganda has been defined as the swelling, big or small, which hangs like scrotum in the neck. Aacharya Charaka has described the disease Galganda in 20 varieties of kaphaj Vikaras ${ }^{(13)}$ and as vitiated Medoj Roga ${ }^{(14)}$. Signs and symptoms of Medoroga i.e., Sthaulya, Dourbalya, tandra, sluggishness, nidradhikya, etc are like hypothyroidism. Aacharya Sushrut, AacharyaVagbhat, Aacharya Madhavakara mentioned separate chapters about Galganda ${ }^{(15,16,17)}$ and described in 3 types i.e., Vatik Galganda, Kaphaj Galganda, Medoj Galganda. And their symptoms like shwaskruccha, gilankashtata, dehavriddhi, bhinnaswara, sirotfullita, bhrama, etc. are like hypothyroidism.

- Kaphavritta Udana-

Here gati of udana vayu is obstructed due to avarana of vitiated kapha, and then it leads to Kaphavritta udana (18). Symptoms of Kaphavritta udana i.e., vaksvargraha (difficulty in speech and voice), Gurugatrata (heaviness in the body), Daurbalya (weakness), Vaivarnya (discolouration), Anannabhilasha (anorexia), etc. are like hypothyroidism.

\section{- Ojovyapat-}

Oja is an essence of all dhatus, which gives strength to the body, improves immunity power, and takes care of well-being of the body. Change in or modification of the natural properties of oja is known as Ojovyapat ${ }^{(19)}$. Symptoms of Ojovyapat i.e., Stabdhata (stiffness), Gurugatrata (heaviness in the body), Vataj Shotha (oedema), varnabhed (discolouration of the skin), glani (Fatigability), Tandra(drowsiness), nidra(sleepiness/somnolence), etc. which are comparatively like symptoms of hypothyroidism.

Table 4: Involvement of Ama in Hypothyroidism

\begin{tabular}{|c|c|}
\hline Symptoms of $A m a^{(20)}$ & Symptoms of Hypothyroidism ${ }^{(21)}$ \\
\hline 1. Srotorodha & Obstruction of the channel \\
\hline 2. Balabhransha & Loss of strength \\
\hline 3. Gaurav & Heaviness in the body \\
\hline 4. Anilamudhata & Delayed tendon reflexes/decreased bowel sound \\
\hline 5. Alasya & Lassitude \\
\hline 6. Apakti & Improper digestion \\
\hline 7. Nishthiva & Spit out/more of expectorations \\
\hline 8. Malsang & Constipation \\
\hline 9. Aruchi & Anorexia \\
\hline 10. Klama & Tiredness \\
\hline
\end{tabular}

Table 5: Involvement of Doshas and strotas in hypothyroidism ${ }^{(22,23)}$ :

\begin{tabular}{|c|c|c|}
\hline Symptoms of Hypothyroidism ${ }^{(24,25)}$ & Doshas Involved $^{(26)}$ & Strotas Involved $^{(27)}$ \\
\hline Weight gain & Kapha & Rasvaha, Medo vaha \\
\hline Loss of appetite & Kapha & Amavaha, Rasvaha \\
\hline Constipation & Vata & Purishvaha \\
\hline The puffy appearance of the body & Kapha & Rasvaha \\
\hline Sluggishness & Kapha & Rasvaha \\
\hline Fatigue/Tiredness & Vata, Kapha & Rasvaha \\
\hline Anaemia/Pallor & Pitta & Rasvaha, Raktvaha \\
\hline Hoarseness of Voice & Kapha, Vata & Pranavaha \\
\hline Dry coarse skin/hair loss & Vata & Asthi vaha, Rasvaha \\
\hline Generalized pain, muscle pain, joint pain & Vata & Asthi vaha, mamsavaha \\
\hline Menstrual disturbances, infertility, loss of libi- & Vata & Artavavaha, Shukra vaha \\
\hline
\end{tabular}




\begin{tabular}{|l|l|l|}
\hline do & Kapha, Vata & Rasvaha \\
\hline Cold intolerance & Kapha & Rasvaha \\
\hline Extreme somnolence, lethargy & Vata, Kapha & Rasvaha, Raktvaha \\
\hline Decrease cardiac output & Vata & Medovaha \\
\hline Decrease in sweat & Vata & Rasvaha \\
\hline Decreased vision, decreased hearing & Vata & Asthivaha, Mamsavaha \\
\hline $\begin{array}{l}\text { Muscles cramps/stiffness } \\
\text { Non-pitting oedema, pericardial effusion, ab- } \\
\text { dominal distension }\end{array}$ & Kapha & Rasvaha \\
\hline $\begin{array}{l}\text { Dull facial expression, depression, impaired } \\
\text { memory, inability to concentrate }\end{array}$ & Vata & Manovaha \\
\hline Osteoporosis & Vata & Asthivaha, Majjavaha \\
\hline
\end{tabular}

- Samprapti of Hypothyroidism with Ayurvedic perspective ${ }^{(28)}$ :

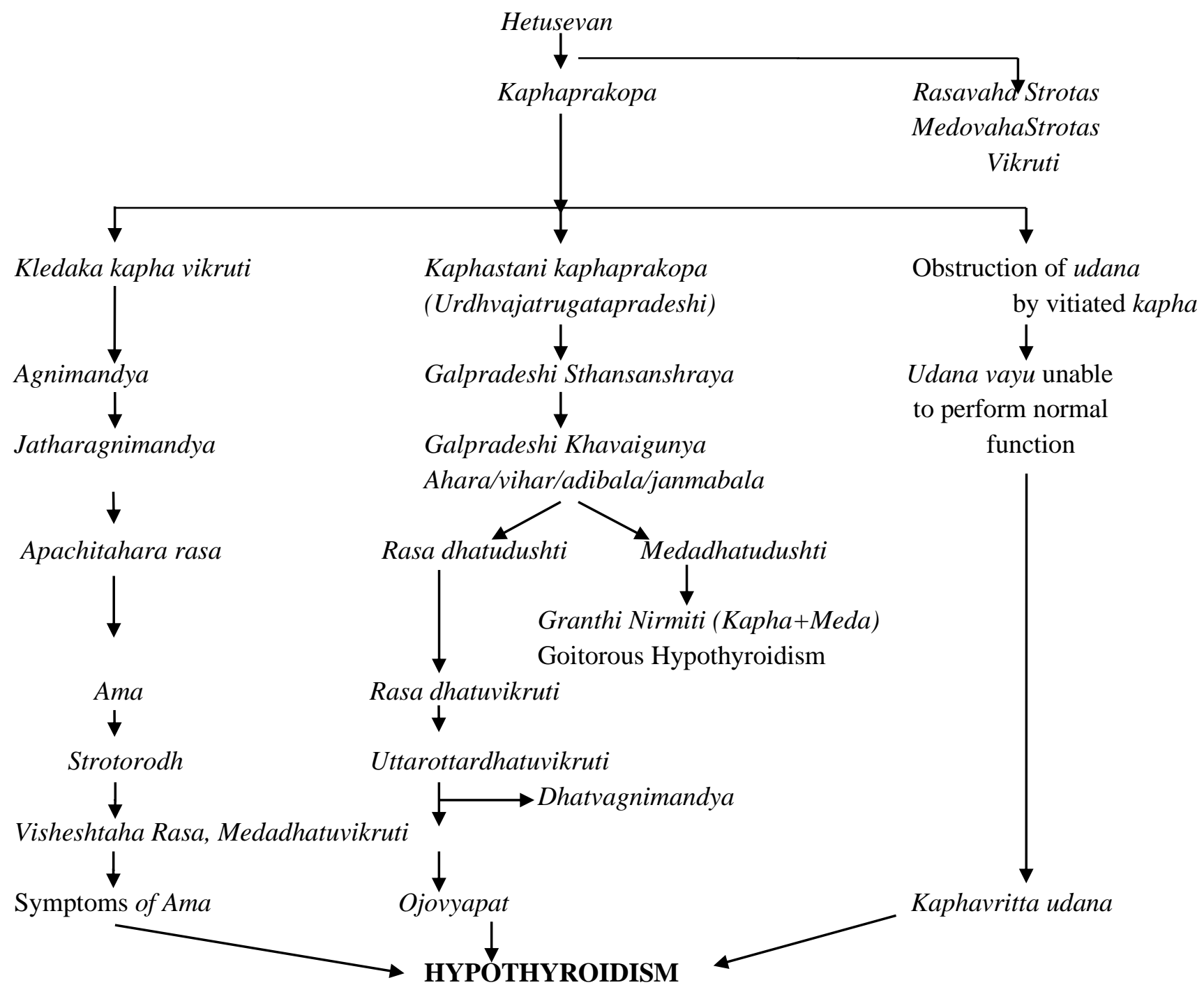




\section{Samprapti Ghataka:}

Dosha- kapha, vata, pitta.

Dushya- Ras and Meda predominantly.

Agni- Jatharagni, Dhatwagni.

Ama- Jatharagnimandyajanit, Dhatwagnimandyajan-

it.

Strotas- Rasvaha and Medovaha(all).

Strotodushti-sang, Vimargagamana.

Adhishthana-Sarvsharir, Gal Pradesh.

Udbhavsthan- Aamashaya.

Vyaktisthan- Sarvsharir.

Rogmarga-Bahya, Abhyantara.

\section{DISCUSSION}

There is no exact correlation of Hypothyroidism in Ayurveda, but its signs and symptoms can be described under Ayurvedic principles. Agni is the main factor for the causation of diseases including Hypothyroidism. Due to Apathyakara Aahar Vihar, Agni gets vitiated and causes the Agnimandya which results in the formation of Apachita Aahara ras called Ama and symptoms of Ama are very similar to Hypothyroidism. On the other hand, due to kaphakara Aahara sevan, there is starting the process of kaphaprakopa at kaphasthan i.e., Galpradesh/urdhvjatrugat Pradesh. Kaphaprakopa form the vitiation of Ras dhatu and meda dhatu predominantly. If the process of vitiation of dhatus gets continued, it leads to dhatwagnimandya, which results in the formation of vitiation of Oja which is the essence of all dhatus, and it causes Ojovyapat. Symptoms of Ojovyapat are hypothyroidism. Due to Kaphaprakopa, Udana vayu is obstructed by vitiated kapha. The throat and neck are circulatory areas of udana vayu. Hence, udan vayu is unable to perform its normal functions, known as kaphavritta Udana while is comparatively like hypothyroidism. In the pathogenesis of hypothyroidism, Medovaha and Rasvaha strotas are predominantly involved. Tridosha is the founding principle of the Ayurvedic system of medicine. They are responsible for maintaining health through the control of all physiological processes of the body and causing disease due to disturbance in their equilibrium state ${ }^{(4)}$. Agni is an im- portant factor for digestion and metabolism in our body. If Agni of the person is vitiated, the shower metabolism in his body should be disturbed, resulting in sick health and disease. Hence, Agni is said to be the base of health ${ }^{(29)}$. So, if finding the pathogenesis of hypothyroidism, Agni dushti is the primary cause and then it results in the uttarottara dhatwagnimandya. The disease Galganda is described in various Ayurveda Samhita, but Galganda occurs in the neck region only and hypothyroidism involves various symptoms of the body, that's why hypothyroidism cannot be compared with only Galganda disease. All endocrine disorders are Aadhyatmik vyadhi as per Ayurveda. Adhyatmik vyadhi manifesting in both body and mind level, which is comparable with hypothyroidism. There are 3 types of Adhyatmik vyadhi and their hetus i.e., Adibalapravritta hetu, Janmabalapravritta hetus and Doshbalapravritta hetus are perfectly matched with causative factors of hypothyroidism. Ashtoninditiya purushas can be considered functional disorders of endocrine glands. Out of which, symptoms of Sthaulya are nearly like hypothyroidism.

\section{CONCLUSION}

On the verge of completion of discussion, it can be concluded that allied complaints of hypothyroidism can be considered as the combined effect of Agni dushti specially Medodhatwagnimandya, derangement of tridosha and dhatus. Pathogenesis of Ojovyapat, Kaphavritta Udana and Ama are considered while treating hypothyroidism. One should not be ashamed of one's inability to name a disease since all disorders cannot be given a standard name. There are innumerable disorders because the same vitiated doshas cause various disorders according to variation in aetiology and locations. Hence, one should initiate any treatment after acquiring complete knowledge of the inherent, nature of the disease, its pathogenesis, origin or site of lesions and locations of presentation, etiological factors, etc. Ayurveda line of management for that is Hetupratyanik chikitsa, Vyadhipratyanik chikitsa and Satvavjay chikitsa i.e., cure the Agni dushti and maintain the balance of doshas and dhatus, 
Give assurance to patients. Also follow proper, healthy food and lifestyle according to Dincharya described in Ayurveda.

\section{REFERENCES}

1. Nikhil Tendon, editor Siddharth N. shah Textbook of medicine, published by The Association of Physicians of India, $8^{\text {th }}$ edi.2008, vol2, chapter no.6, pg no. 1003.

2. Ambika Gopalkrishnan, Prevalence of Hypothyroidism in an adult-An epidemiological study in eight cities of India, Indian Journal of Endocrinology and Metabolism, Jul-Aug 2013. http://www.ijem.in.

3. Ambika GopalKrishnan Unnikrishnan and Usha $\mathrm{v}$ Menon, Thyroid disorders in India: An epidemiological perspective, Indian journal of Endocrinology and Metabolism, jul 2011.

4. Hetal Amin, Rohit Sharma, A comparative review study of Tridosha VIS-À-VIS Endocrine glands, World Journal of pharmacological research and technology, Feb 2016.

5. VD.Y.G. Joshi, Charak Samhita with Shree chakrapani data virachit Ayurvedadeepika vyakhya, Marathi commentary, Vaidhyamitra Prakashan, Pune, $1^{\text {st }}$ edi 2003, vol 2, chapter 15, shloka no.3, pg.no.339.

6. VD.Y.G. Joshi, Charak Samhita with Shree chakrapani data virachit Ayurvedadeepika vyakhya, Marathi commentary, Vaidya Mitra Prakashan, Pune,1st edi 2003, vol 2, chikitsa sthan, chapter 15, shloka no.7,13,15, pg.no.340,343.

7. Dr Ambika Datta Shastri, Sushrut Samhita, Ayurveda tatvasandipika Hindi commentary, Chaukhamba Sanskrit sansthan, Banaras, 2013, vol 1, sutrasthan, chapter no.15, Shlok no.5, pg no.74.

8. K Sembulingam and prema Sembulingam, Essentials of medical physiology, Jaypee brothers' medical publishers (p) LTD, $3^{\text {rd }}$ edi 2005, chapter no.67, pg no. 316,317,318.

9. DR. GaneshKrushna Garde, Sarth Vagbhat, Vagbhatkurta Ashtangahrudaya, Marathi commentary, Rajesh prakashan, Pune. Sutrasthan, chapter no.11, shlok no.4, pg no.52.

10. Nikhil Tandon, editor Siddharth N. shah, API Textbook of Medicine, published by The Association of Physicians of India, $8^{\text {th }}$ edi 2008 , vol 2, chapter no.6, pg no. 1007

11. Dr Bramhanand Tripathi, Charak Samhita, CharakChandrika Hindi commentary, Chaukhamba Surbha- rati Prakashan, Varanasi 2019, vol 1 sutrasthan, chapter no 21, shloka no 4, pg no.399.

12. Dr Ambika data shastri, Sushrut Samhita, Ayurvedatatvasandipika Hindi commentary, Chaukhamba Sanskrit sansthan, Banaras, 2013, vol 1, Sutrasthan, chapter no, 24, shloka no.4-6, pg no.129, 130.

13. Dr Brahmanand Tripathi, CharakSamhita, Charak Chandrika Hindicommentary, Chaukhamba Surbharti Prakashan, Varanasi2019, vol 1, sutrasthan, chapter no.20, shloka no.17, pg no.395.

14. Dr Brahmanand Tripathi, Charak Samhita, CharakChandrika Hindi commentary, chaukhamba SurbhartiPrakashan, Varanasi 2019, vol 1, sutrasthan, chapter no 28 , shloka no.14, pg no.548.

15. Dr Ambika Datta Shastri, Sushrut Samhita, Ayurvedatatvasandipika Hindi commentary, chaukhamba Sanskrit sansthan, Banaras, 2013, vol 1, Nidanasthana, chapter no.11, shloka no.23-30, pg no.355,356.

16. Dr Ganesh Krushna Garde, Sarth Vagbhat, Vagbhatkurta Ashtang Hridya, Marathi commentary, Rajesh publication, Pune, Uttarsthan, chapter no.21, shloka no.53-56, pg no.414.

17. Ayurvedacharya Shree Yadunandanopadhyay, Madhav Nidanam, Madhukoshavyakhya, Chaukhamba prakashan, Varanasi, 2009, vol 2, Nidanasthana, chapter no.38, shloka no.1-7, pg no.75-78.

18. VD.Y.G. Joshi, Charak Samhita, Shree chakrapani data virachit Ayurveda deepikavyakhya, Marathicommentary, Vaidhyamitra prakashan, Pune, $1^{\text {st }}$ di 2003, vol 2, chikitsasthan, chapter no.28, shloka no.224, pg no.652.

19. Dr Ambika data shastri, Sushrut Samhita, Ayurvedatatvasandipika Hindi commentary, Chaukhamba Sanskrit sansthan, Banaras, 2013, vol 1, sutrasthan, chapter no.15, shloka no.29.pg no.80.

20. Dr Ganesh Krushna Garde, Sarth Vagbhat, Vagbhatkurta Ashtangahrudaya, Marathi commentary, Rajesh prakashan, Pune, sutrasthan, chapter no.11, shloka no.4, pg no.52.

21. Aswathy Prakash, Understanding Hypothyroidism in Ayurveda, International Ayurvedic Medical Journal, Nov 2015.

22. Dr Seema H Thakare, DrRajni K Gurmule, A Review on Hypothyroidism-An Anuktavyadhi in Ayurveda, PARIPEX-Indian Journal of Research, Jun 2019.

23. Kadlaskar B. B., Hypothyroidism in Ayurveda-A Conceptual study, An International Journal of Research in AYUSH and Allied system, July 2015. 
24. Nikhil Tandon, editor Siddharth N Shah, API Textbook of Medicine, published by The Association of physicians of India. $8^{\text {thedi }} 2008$, vol 2, chapter no.6, pg no. 1008 .

25. K Sembulingam, Preema Sembulingam, Essentials of Medical Physiology, Jaypee brothers' medical publishers(p) LTD, $3^{\text {rd }}$ edi 2005, chapter no.67, pg no.321.

26. Dr Brahmanand Tripathi, Charak Samhita, CharakChandrika Hindi commentary, chaukhamba Surbharti prakashan, Varanasi,2019, vol 1, sutrasthan, chapter no.20, shloka no.11,12,17, 18. pg no.391,395.

27. Dr Brahmanand Tripathi, Charak Samhita, CharakChandrika Hindi commentary, Varanasi, 2019, vol 1, sutrasthan, chapter no.28, shloka 9-19, pg no.548,549.

28. Dr Kalaskar Anand, Study of hypothyroidism as an Anuktavyadhi, International Ayurvedic Medical Journal, Aug. 2016.

29. Vd Y G Joshi, Charak Samhita, Shree chakrapani data virachit Ayurveda deepika vyakhya, Marathi commentary, Vaidya Mitra prakashan, Pune, $1^{\text {stedi }} 2003$, vol 2 , chikitsasthana, chapter no 15 , shloka no. 4 , pg no 339 .

\section{Source of Support: Nil \\ Conflict of Interest: None Declared}

How to cite this URL: Welde Amruta \& Pawar Pradeep: Critical Study of Hypothyroidism in The Light of Ayurved Perspective. International Ayurvedic Medical Journal \{online\} 2021 \{cited November 2021\} Available from: http://www.iamj.in/posts/images/upload/2815 2822.pdf 